\title{
THE ROLES OF EXTERNAL AUDITORS AND BANK INSPECTORS IN THE DISTRESS CONDITION OF BANKS EVIDENCE FROM ZAMFARA STATE, NIGERIA
}

\author{
TAYO AWE \& MUHAMMAD USAINI \\ Dept of Accounting and Finance \\ Faculty of Management and Social Sciences, \\ Federal University Gusau, \\ Zamfara, Nigeria.
}

https://doi.org/10.37602/IJSSMR.2020.3301

\begin{abstract}
Banks were liquidated due to poor capital base, insider abuse and mismanagement. Also, other problems ravaging banks are forgeries, frauds and financial indiscipline etc. this posed great challenges to management. Here the work of the auditors set in; the primary duty of the auditor is to report on truth and fairness of the financial statement. The paper focuses on the role of auditor's and inspectors reviving the true banking culture. The researcher adopted survey method of data collection. Data required were collected through the distribution of the questionnaire, personal interview, oral interview from respondents and a sample size of 18 . The statistical tool used for this work is chi-square. The researcher finds out that the distress conditions of banks today is due to the fact that Auditors and Inspectors had failed in their duties and Banks does not keep to the GAAAP in their daily transactions. The researcher recommended that Implementation of recommendation report, insurance training from banking instructors, enhancement of welfare scheme, commensurate remuneration for external auditors and use of technology should be used to carry out their duties effectively.
\end{abstract}

Keywords; External Auditors, Bank Inspectors, Distress Condition, Banks.

\subsection{BACKGROUND}

The idea of banks inspection and external auditing evolved over the years. It is not a new phenomenon neither is it a product of distress condition in the banks due to varying degrees and complexities of the business of these classes of professionals as indispensable. While the bank's inspectors serve the role of internal Auditors in the banking institutions, the external Auditor is the statutory shareholder watchdog. Bank inspectors ensure that management directives and policies are complied with especially as its effect disbursement of depositor's funds. Several banks were unable to pay account from people's deposit and vaults. These were due to other factors among which include: high-interest rate, none repayment of loans and advances, excessive debts, insufficiency in the banking operations, lack of security to debt frauds, forgeries etc. These and more were responsible for these financial problems. Therefore it became necessary that neither management nor the shareholders were present at the scene of the actual execution of banks policies and regulations. The inspectors are 


\section{International Journal of Social Sciences and Management Review}

appointed with the sole aim of visiting branches to ensure that policies, especially as it affects granting of loans and collaterals are strictly adhered to. They are always expected to make a report of their findings, and in most cases recommend disciplinary measure for the erring of managers. The inspectors known as the Internal Auditors are the employees of the bank. They must be independent of the entire administrative operating department. In their words, the internal audit department should be a separate department in its own rights. The objectives of internal checks or auditing are therefore to assist all members of the management in the effective discharge of their responsibilities by furnishing them with analysis appraisals, recommendations and pertinent comments concerning activities reviewed. Internal Auditors are concerned with any phase of business activity in which they will be of interest to the bank. This involves going beyond the accounting and financial records to obtain a full understanding of the operations under review. It can, therefore, be said that Bank Inspection s an independent appraisal function within a banking institution for the monitoring of the various checks and balances in order to ensure the control of and quality of performance. It is a system of checking operations in the banking industry and this routine check is continuous in nature, being undertaken by staffers engaged for that purpose. Since however, the inspector is an employee of the bank, His independence is not always a guarantee. Theoretically, he is meant to perform his duties in absolute freedom but in actual practice, it is not always the case. In most cases, in the distress condition of banks, management is the culprits in violating their own policies. In this case, the inspectors become helpless when management refuses to subject itself laid down rules and regulations. Who are the inspectors going to report to concerning violations of lending policies? It becomes obvious that the inspectors are handicapped to the extent which management decides to abuse its laid down policies.

Statutory Audit per se is concerned mainly with an expression of opinion on the performance of management, which is shown by financial statements it presented to the shareholders. It is expected that the financial statement is presented to the shareholders. It is expected that the management has the responsibility of detecting fraud if any. In this class of audits, the duties of the auditor are clearly spelt out in section 360 and schedule 6 of the Companies and Allied Matters Decree 1990. Such duties can be greatly extended by additional instruction from clients, but cannot in any way be reduced. For statutory audits, it is essential for the auditor to exercise absolute independence. The procedure for is 1990 appointment removal and remuneration must conform to the provision of section 357,362 and 361 respectively of the Company and Allied Matters Decree 1990. These two types of audits have a common interest, which ascertaining that there is an effective system of internal checks operating satisfactorily and an adequate accounting system capable of providing the information necessary to prepare true and fair financial statements. There are some fundamental differences which include:

\subsection{RESEARCH PROBLEM}

Poor capital base, mismanagement and insider's abuse, Management Aided Fraud and Lack of punishment to deter fraud and forgeries

\subsection{REVIEW}




\section{International Journal of Social Sciences and Management Review}

A review of related literature is deemed necessary for reviewing different literature on the subject under study and to bring out relevant facts on the similar work done by others in the past and then relate it to the present research work it also determine and convey understanding to the appreciation of what the researcher has intended to achieve. In this chapter several issues, articles test and comment relating to various aspect of the study are diffused artificially. This is necessary because it provides good information both to the researcher and others who may like to make use of the research work.

\subsection{NATURE AND IMPLICATION OF FINANCIAL DISTRESS IN BANKS}

Financial distress in the Nigeria financial system is a problem that as of recent assumed an intractable dimension. The situation is such that the regulatory authorities appear to be fighting a costing battle in their bid to sanitize the system. The phenomenal growth of banks following the introduction of the structural adjustment program created a false impression that banking is an all-comer business. Hence the banking sector was besieged by all types of investors who have surplus funds to throw about. Not only did incompetent and inexperienced management personnel assumed a very senior position in some banks, but people with very clean credentials also join the bandwagon. The entry of facing the monetary authorities is how to curtail the various so that it does not spread to other banks. Besides the general macroeconomic instability resulting in the unpredictable monetary policy, the environment has equally played a significant role in bringing about distress in banks.

A bank is classified as distress based on the bank examination rating system with acronym CAMEL: that is Capital, Adequate assets quality, Management competence, Earnings strength, liquidity sufficiency and sensitivity to market risk. CAMEL rating ranges on a numerical scale from 1 to 5 with 1 being the best band 5 the worst. According to the FDC'S DSC Risk management manual of examination policies (pp 1.1 -2- 1.1-3), each rating component is assigned a score of 1-5 to determine a composite score. The composite scoring process uses subjective weighting of the components based on particulars circumstances associated with an individual bank rather than calculating an arithmetic average or assigning predetermined weight to the components.

Akpala (1995) observed a financially distressed bank as banks which are generally in a poor financial condition and which by extension has a serious implication for rendering it insolvent. CBN defined distress bank as a situation where a bank fails to meet its capitalization requirement or has a weak deposit base and afflicted y management. Where depositors fear the loss of their deposit and a consequent breakdown of contractual obligations., While a bank is said to be liquid when it could no longer meet its liabilities as they mature for payment it is said to be insolvent when the value of its liabilities a case of the negative network. These could lead to a bank run as depositor's lost confidence in the system and seeks to avoid capital loss. Insolvency in the banking industry refers to a condition in which the sum of a bank's assets is less than the sum of its liabilities including the capital. A bank's inability to honour the current customer's obligations means the bank is not liquid. Agulu (2007). A bank that is not liquid would typically be forced to suspend payment to its depositors, perhaps for short periods or default on monetary claims such as inter-bank placement. Ademu (2007), A distressed bank is however different from a failed bank which is defined by the failed bank decree as a bank or financial institution whose license has been 


\section{International Journal of Social Sciences and Management Review}

Volume: 03, Issue: 03 “May - June 2020”

ISSN 2582-0176

taken over by CBN or the NDIC. It is perceived as a bank which is unable to meet its obligations to its shareholders as at when due arising from weakness in its financial and managerial condition could have rendered it either not liquid or insolvent (CBN, NDIC 1995).

Banking distress has a serious negative consequence for the economy as a whole and for the banking sector in particular, for banking operators and customers. Distress undermines the ability of banks to discharge their role of credit delivery and impairs the capacity to render other services to industry. Distress causes a generalize depression in the banking sector, which in turn tend to mobilize the entire economy. No economy can grow or prosper if the banking sector remains distress for too long. The first direct impact of banking distress, therefore, is to accelerate the rate of depression in the overall economy. The immediate impact of banking distress of cause is on the sub-sector itself. Modern banking represents a chain of indebtedness. The wakening of lack in that chain is bound to affect the strength and the reliance of the entire system. Consequently, distress in one bank can easily be transmitted to the other banks with which the affected banks maintain the operational relationship. Distress in the bank also erodes public confidence in banking as a whole. Extreme caution, fear and loss of confidence among bank customers result in deposit flight, which exacerbates distress by deepening the liquidity situation of the banks. Generalized loss of confidence in the ability of banks to survive a protracted period of distress could lead to a total collapse of the payment system. Bank customers experience a lot of difficulties from bank distress. Customers' deposits are inevitably trapped in distress bank thus creating extreme hardship for customers and their families. Many Nigerians have suffered severe depression because of the loss of access to their life savings trapped in distressed banks. Owners of distressed banks are exposed to a partial or total loss of their investment. Most of the distressed banks in Nigeria have a negative network.

\subsection{EMPIRICAL FRAMEWORK PRE AND POST CONSOLIDATION OF NIGERIAN BANKING SECTOR}

According to a report by international corporate research (ICR) 2010, the Nigerian banking system, which is regulated by the central bank of Nigeria is made up of deposit money banks referred to as commercial banks, development finance institutions and other financial companies, bureau de change, discount houses and primary mortgage institution.

The origin of banking in Nigeria industry can be dated back to the colonial era, precisely in 1894, when the bank of British West Africa was established in Lagos in a bid to facilitating business between Nigerians and British colonists. Distress in the banking industry was first experienced in Nigeria between 1930 and 1950 when some banks failed and were recorded in Nigeria between 1930 1nd 1958 when the CBN was established. Examples of such banks are Alpha Merchant Bank, ABC Merchant Bank (CBN statistical bulletin 1988). Smith and Walker (1997) noted that the failure of a bank has a great adverse effect on the economy only and so it is considered very important. As regards the commercial banks, according to the official liquidator (CBN statistical bulletin 2000), the Nigerian government established a special method to ease the distress of depositors and affected employees of commercial banks. It cost the government 20 billion nairas to respond to the interest of depositors and employees (CBN statistical bulletin September 2001). 


\section{International Journal of Social Sciences and Management Review}

The CBN under the government of Charles Soludo in 2004 increased the minimum paid-up capital of banks to 25 billion nairas (US \$173million) from $\$ 2$ billion (US $\$ 14$ million). The policy which was effective in 2005 was intended to consolidate the existing banks into fewer, larger and financially stronger banks as a result of the implementation of the policy, the 89 banks that existed as at 2004 decreased to 25 larger, better-capitalized banks in 2005 . In 2010 , the CBN, however, came up with another policy, which is a fundamental reversal o the consolidation policy in 2005. The new policy was aimed at categorizing banks by functions and allowing varying levels of capital depending on the banks function as opposed to the single current minimum capital of 25 billion nairas. Sanusi (2010) opined that the banks did not fail; they were destroyed and brought to their knees by acts committed by identifying people. He further noted that the banking industry has been cajoled and manipulated by shares holder, the management that stole money in the name of borrowing the gamblers that took depositors fund to stipulate on the stock market and manipulate share prices, the billionaires and captains of industry whose wealth actually was money belonging to the poor which they borrowed and refuse to pay back. All this has contributed in small measure to the distress of banks in Nigeria.

\subsection{PREVENTIVE MEASURES}

The dictum that prevention is better than cure is very apt in the management of bank distress. In a bid to prevent the distress, the regulatory authorities often impose a number of operational controls on banks. Such measures which are designed to promote sound financial conditions in the banks include the following among others:

i. Banks are required to maintain and build up a reserve in order to pup up the capital base of the banks. The imposition of minimum share capital as well as other capital adequacy requirement governing provision.

ii. Measures designed to control credit expansion as well as those meant to discourage loan concentration on industrial borrowed on economic sectors and other imposition of both NDIC and the CBN to ascertain the financial condition of banks as well their compliance with operating guidelines.

\subsection{RESEARCH METHODOLOGY}

Having explained the various thoughts and theories of banks distress phenomenon in Nigeria, including the roles played by auditor and management. The researcher is now concern with examining the procedure employed in carrying out the study. These procedures include research method and design, the population of the study, sample and sampling procedure, instrument of data collection, validity of the instrument used, reliability of the instrument used, method of data collection, and method of data analysis and statistical method of analysis.

\subsection{STUDY AREA, SAMPLE SIZE AND SAMPLE PROCEDURE}

Though the study is a case, the researcher chooses to survey and sample data from some banks in Nigeria being unable to reach all the bank in Nigeria, these banks are; Polaris Bank, FBN, GTB, UBA, Diamond Bank all in Zamfara State. 


\section{International Journal of Social Sciences and Management Review}

Volume: 03, Issue: 03 “May - June 2020”

ISSN 2582-0176

The staff strength of the bank is;

Polaris bank=60, FBN=90, UBA=45, GTB=75, Diamond bank=50.

From the population given above the researcher was able to arrive at an effective sample size derived from the formula below:

$\mathrm{S}=\mathrm{N} \sqrt{N-1}$

Where $\mathrm{S}=$ Sample size, $\mathrm{N}=$ Population

Note: The formula is in used when the variance and standard deviation are known.

$\mathrm{S}=? \quad \mathrm{~N}=320$

$\mathrm{S}=320 \underline{\sqrt{320}}=320 \underline{\sqrt{320}}=18$

$320-1 \quad 319$

\subsection{VARIABLE DESCRIPTION}

Hence the researcher selected the survey method for the purpose of this study. The researcher designed a questionnaire of 20 questions well balanced and directed to the problem under investigation. The answer could be Yes or No and some items written statement expected from the respondents. More so, the personal and oral interview was conducted to the largest groups namely from directors, managers, auditors, inspectors and other general duty staff including some effective shareholders and prominent shareholders of the banks.

\subsection{INSTRUMENTS FOR DATA COLLECTION}

As earlier stated in the data collection method, the researcher used and applied both methods of data collection i.e. primary and secondary data.

a) Primary data: Here the researcher sources data from the following source they are created or established through first-hand research, they are original in that the researcher is first to use them. The researcher sourced data from the following: questionnaire, personal interview and oral interview.

b) Secondary data: Here, the researcher made use of books, magazines, newspapers, seminar/workshop papers, journals/bulletin and course materials.

\subsection{METHOD OF DATA ANALYSIS}

Chi-square (X-1) is a method of testing hypothesis measuring the reliability and significance of data whether the deviations of the actual observations (observed frequency) from the rejection or acceptance of the null hypothesis or otherwise. Asika (1991:50)

$\mathrm{X} 2 \Sigma(\mathrm{O}-\mathrm{e}) 2$

Where; $\Sigma=$ summative sign, $\mathrm{O}=$ observed frequency, $\mathrm{E}=$ expected frequency $\mathrm{X} 2=$ Chi square test. 


\section{International Journal of Social Sciences and Management Review}

Volume: 03, Issue: 03 “May - June 2020”

ISSN 2582-0176

For a given significance level and a number of degrees of freedom. I.e. the usual hypothesis testing procedure. By this test, the researcher wishes to answer the question in this computed value $\mathrm{X} 2$ so large that we are unwilling to attribute the difference between observed frequency $(\mathrm{O})$ and expected frequency $(\mathrm{E})$ to chance and therefore have to reject the null hypothesis $(\mathrm{HO})$ in order to apply the $\mathrm{X} 2$ test a certain level of confidence margin of error has to be assumed and also the number of degrees of freedom I the table determine i.e. general. The degree of freedom (df) is given by $(\mathrm{m}-1)(\mathrm{n}-1)$ or $(\mathrm{r}-1)(\mathrm{e}-1)$ and the chi-square (X2). The distribution table determines the value of X2 in terms of an assumed level of significance where:

$\mathrm{R}=$ number of rows, $\mathrm{C}=$ number of columns.

The researcher assumed 90.05 level of significance in testing hypothesis 1 i.e. $95 \%$ confidence level of 0.01 level of significance in testing hypothesis ii i.e. $99 \%$ confidence level.

\subsection{DECISION RULE}

The decision rule to accept $\mathrm{HO}$ if the computed $\mathrm{X} 2$ is less than or equal to the $\mathrm{X} 2$ and to reject $\mathrm{HO}$ if $\mathrm{X} 2$ calculated is greater $(>) \mathrm{X} 2$ values in the distribution table.

$\mathrm{HO}=$ Null hypothesis

$\mathrm{HO}=$ Alternative hypothesis

\subsection{DATA PRESENTATION AND ANALYSIS}

This Chapter forms the real basis of the research work because it presents an analysis of the various data collection and giving an interpretation to the result of the analysis. Therefore it is available for the users of this work to provide a good idea and parameters for decision making.

Table 4.1 Questionnaire Distribution

\begin{tabular}{|c|c|c|c|c|c|c|}
\hline \multirow[t]{2}{*}{$\mathrm{ES}$} & \multicolumn{3}{|c|}{ Departments } & \multirow{2}{*}{$\begin{array}{c}\text { No } \\
\text { Distributed }\end{array}$} & \multirow{2}{*}{$\begin{array}{c}\text { No } \\
\text { Collected }\end{array}$} & \multirow[t]{2}{*}{$\%$} \\
\hline & Ad & $\mathrm{A} / \mathrm{cs}$ & Inspect & & & \\
\hline GTB & 1 & 1 & 1 & 3 & 3 & $100 \%$ \\
\hline UBA & - & 1 & 1 & 2 & 2 & $100 \%$ \\
\hline Diamond & - & 2 & 1 & 3 & 2 & $67 \%$ \\
\hline $\mathrm{FBN}$ & 1 & 2 & 2 & 5 & 4 & $80 \%$ \\
\hline Polaris & 2 & 2 & 1 & 5 & 5 & $100 \%$ \\
\hline Total & 4 & 8 & 6 & 18 & 16 & $89 \%$ \\
\hline
\end{tabular}




\section{International Journal of Social Sciences and Management Review}

Volume: 03, Issue: 03 “May - June 2020”

ISSN 2582-0176

Source: field work, 2018.

Table 4.1 shows the nature of the distribution and of the questionnaire. In all twenty questions prepared and distributed to the target groups and department for GTB 3 questionnaire were served and all were returned i.e 100\%. For UBA 2 questionnaires were served and all were returned i.e 100\%. For Diamond Bank 3 questionnaire were served and 2 were returned i.e 67\%. For FBN 5 Questionnaire were served and 4 were returned that is $80 \%$ and for Polaris Bank 5 questionnaire were served and all were returned i.e 100\%. The high percentage recorded indicates the good and effective interest of the respondents towards the work.

Table 4.2 RESPONSE RATE

\begin{tabular}{|l|c|c|c|}
\hline Questionnaire & No. of Copies & Workings & Response \\
\hline Completed \& Returned & 16 & $16 / 18 \times 100$ & $89 \%$ \\
Not Returned & 2 & $2 / 18 \times 100$ & $11 \%$ \\
\hline Total & 18 & & $100 \%$ \\
\hline
\end{tabular}

Source: field work, 2018.

From the Table 4.2, 18 questionnaires were served and 16 respondents returned while 2 were not returned indicating $89 \%$ and $11 \%$ respectively of the response to the positive results expected from the study.

Table 4.3: Table of Staff Disposition (Target Groups)

\begin{tabular}{|c|c|c|c|c|c|}
\hline Establishment & Directors & Managers & $\begin{array}{l}\text { Auditors/ } \\
\text { Inspectors }\end{array}$ & $\begin{array}{l}\text { Allied } \\
\text { Staff }\end{array}$ & Total \\
\hline Polaris & 1 & 2 & 1 & 1 & 5 \\
GTB & - & 1 & 1 & - & 3 \\
UBA & - & 1 & 1 & - & 2 \\
Diamond & - & 2 & 1 & - & 3 \\
FBN & - & 2 & 2 & 1 & 5 \\
\hline Total & 1 & 8 & 6 & 2 & 18 \\
\hline
\end{tabular}

\section{Source: field work, 2018.}

From Table 4.318 questionnaires were distributed to target staff groups namely: Directors, Managers, Auditors/inspectors and Allied staff. Polaris Bank has 1 Director, 2 managers, 1 inspectors and 1 allied staff. GTB has 1 manager, 1 inspector and 1 allied staff. UBA has 1 manager and 1 inspector. Diamond Bank has 2 managers and 1 inspector while FBN has 2 managers, 2 inspectors, and 1 allied staff.

Table 4.4 Table of Sex Distribution 


\section{International Journal of Social Sciences and Management Review}

Volume: 03, Issue: 03 "May - June 2020"

ISSN 2582-0176

\begin{tabular}{|c|c|c|c|c|c|}
\hline Options & Establishment & \multicolumn{2}{|c|}{ Department } & Total \\
\hline M & & Advance & $\mathrm{A} / \mathrm{cs}$ & Inspect & \\
F & Polaris & - & - & - & - \\
\hline M & & 1 & - & 1 & 2 \\
F & GTB & - & 1 & - & 1 \\
\hline M & & - & 1 & 1 & 2 \\
F & UBA & - & - & - & - \\
\hline M & & - & 1 & 1 & 2 \\
F & Diamond & - & - & - & - \\
\hline M & & 1 & 1 & 2 & 4 \\
\hline F & FBN & - & - & - & - \\
\hline Total & & 4 & 6 & 6 & 16 \\
\hline
\end{tabular}

\section{Source: field work, 2018.}

From the above Table 4.4, the researcher shows that almost all the respondent were male from the sex distribution with only one female from GTB and 2 male from the same bank. All the respondents from other banks were male.

Table 4.5 Educational Background.

\begin{tabular}{|l|c|c|c|c|c|}
\hline Questionnaire & Establishment & \multicolumn{3}{|c|}{ Departments } & Total \\
\hline & & Ad & A/cs & Insp. & \\
\hline WASC & & - & - & - & - \\
DIP & & - & - & - & - \\
BSC & Polaris & 1 & - & - & 1 \\
MBA/MSC & & 1 & 2 & 1 & 4 \\
WASC & & - & - & - & - \\
DIP & & - & - & - & - \\
BSC & & - & 1 & - & 1 \\
MBA/MSC & GTB & 1 & - & 1 & 2 \\
\hline
\end{tabular}




\section{International Journal of Social Sciences and Management Review}

Volume: 03, Issue: 03 “May - June 2020”

ISSN 2582-0176

\begin{tabular}{|l|c|c|c|c|c|}
\hline WASC & & - & - & - & - \\
DIP & & - & - & - & - \\
BSC & & - & - & - & - \\
MBA/MSC & UBA & - & 1 & 1 & 2 \\
\hline WASC & & - & - & - & - \\
DIP & & - & - & - & - \\
BSC & Diamond & - & - & - & - \\
MBA/MSC & & - & 1 & 1 & 2 \\
\hline WASC & & - & - & - & - \\
DIP & & - & - & - & - \\
BSC & FBN & - & - & - & - \\
MBA/MSC & & 1 & 1 & 2 & 4 \\
\hline Total & & 4 & 6 & 6 & 16 \\
\hline
\end{tabular}

\section{Source: field work, 2018.}

From Table 4.5 one can see that the responses for the banks under investigation are all literate. These qualifications cut across BSC and MSC/MBA. Polaris bank has a person with MBA/MSC and 1 BSC holder. UBA has 2 MBA/MSC holders; GTB has 1 BSC and 2 MSC holders. Diamond bank $3 \mathrm{MBA} / \mathrm{MSC}$ staff and all the respondents from FBN are MBA/MSC staff and all the respondents from FBN are MBA/MSC holders. From this analysis one can confirm the reliability, the validity of the information to be given by these groups. This null information etc. thereby confirming the results of the researcher's test analysis.

Table 4.6: Table of Work Experience

\begin{tabular}{|c|c|c|c|c|c|}
\hline Questionnaire & Establishment & \multicolumn{3}{|c|}{ Departments } & Total \\
\hline & & Ad & A/cs & Insp. & \\
\hline $1-10$ & & - & - & - & - \\
$11-20$ & Polaris & - & - & - & - \\
$21-35$ & & & & & \\
& & & & & \\
\hline
\end{tabular}




\section{International Journal of Social Sciences and Management Review}

Volume: 03, Issue: 03 “May - June 2020”

ISSN 2582-0176

\begin{tabular}{|c|c|c|c|c|c|}
\hline $\begin{array}{l}1-10 \\
11-20 \\
21-35\end{array}$ & . & $\begin{array}{l}1 \\
-\end{array}$ & - & - & $\begin{array}{l}1 \\
2 \\
-\end{array}$ \\
\hline $\begin{array}{l}1-10 \\
11-20 \\
21-35\end{array}$ & UBA & - & $\begin{array}{l}1 \\
-\end{array}$ & - & $\begin{array}{l}- \\
2 \\
-\end{array}$ \\
\hline $\begin{array}{l}1-10 \\
11-20 \\
21-35\end{array}$ & Diamond & $\begin{array}{l}- \\
-\end{array}$ & $\begin{array}{l}- \\
1 \\
-\end{array}$ & $\begin{array}{l}- \\
1 \\
-\end{array}$ & $\begin{array}{l}- \\
2 \\
-\end{array}$ \\
\hline $\begin{array}{l}1-10 \\
11-20 \\
21-35\end{array}$ & & - & $\begin{array}{l}- \\
1 \\
-\end{array}$ & $\begin{array}{l}- \\
1 \\
-\end{array}$ & $\begin{array}{l}- \\
2 \\
-\end{array}$ \\
\hline Total & & 4 & 6 & 6 & 16 \\
\hline
\end{tabular}

\section{Source: field work, 2018.}

From Table 4.6 dealing with working experience, it would be observed that the respondents of the various departments of the banks had reasonable work experience particularly those with $11-20$ years are in the majority. This also confirms the researchers desire to ascertain information from those with reasonable working experience be that the objective of the research work could be achieved and relied upon.

\subsection{DATA ANALYSIS}

In this section, the researcher now goes on to the real statistical test in order to carry out the researcher's objectives that are to determine the role of the auditors in financial distress of banks in Nigeria. In response, the researcher selected four questions from the administered questionnaire namely to question $17,18,19$ and 20 . The result of this test which uses the Chi square (x2) will determine the researcher direction and thus the decision. 


\section{International Journal of Social Sciences and Management Review}

Volume: 03, Issue: 03 "May - June 2020"

ISSN 2582-0176

Question No.17: Analysis of data 1 in your daily transactions and Accounting/Auditing practice, does your bank keep to the generally accepted Accounting/Auditing standard?

Table 4.7

\begin{tabular}{|l|l|c|c|c|c|}
\hline Questionnaire & Establishment & \multicolumn{2}{|c|}{ Department } & Total \\
\hline & & Ad & A/cs & Insp. & \\
\hline Yes & Polaris bank & 2 & 2 & 1 & 5 \\
\hline Yes & & - & - & - & - \\
No & GTB & 1 & 1 & 1 & 3 \\
\hline Yes & & - & - & - & - \\
No & UBA & - & 1 & 1 & 2 \\
\hline Yes & & - & - & - & - \\
\hline No & Diamond bank & - & 1 & 1 & 2 \\
\hline Yes & & - & - & - & - \\
\hline No & FBN & - & 1 & 1 & 2 \\
\hline Total & & - & - & - & - \\
\hline
\end{tabular}

Source: field work, 2018.

From table 4.7 all respondent agree to the questionnaire that they comply and apply the practices of generally accepted accounting/ auditing standard.

\section{Question 18}

In your opinion do you believe that the distress condition of banks today is due to the fact that accounting/ inspectors had failed in their roles, duties and responsibilities?

Table 4.8

\begin{tabular}{|l|l|c|c|c|c|}
\hline options & Bank & \multicolumn{2}{|c|}{ Department } & Total \\
\hline & & Ad & A/cs & Insp. & \\
\hline Yes & Polaris banks & 2 & 2 & - & 4 \\
No & & - & - & 1 & 1 \\
\hline Yes & GTB & 1 & 1 & - & 2 \\
\hline
\end{tabular}




\section{International Journal of Social Sciences and Management Review}

Volume: 03, Issue: 03 "May - June 2020"

ISSN 2582-0176

\begin{tabular}{|l|l|c|c|c|c|}
\hline No & & - & - & 1 & 1 \\
\hline Yes & UBA & - & 1 & 1 & 2 \\
\hline Yes & & - & - & - & - \\
No & Diamond bank & - & 1 & 1 & 2 \\
\hline Yes & FBN & - & - & - & - \\
No & & 1 & 1 & - & 2 \\
\hline Total & - & - & 2 & 2 \\
\hline
\end{tabular}

Source: field work, 2018.

From table 4.812 person agreed to the point that the distress of the bank is due to the fact that Auditors/Inspectors had failed in their duties and responsibilities while 4 persons disagree.

\section{Question 19}

Do you attribute or blame management for the incompetence, inefficiency, ineffectiveness or otherwise?

Table 4.9

\begin{tabular}{|l|l|c|c|c|c|}
\hline options & Bank & \multicolumn{2}{|c|}{ Department } & Total \\
\hline Yes & & Ad & A/cs & Insp. & \\
No & Polaris bank & 2 & 2 & 1 & 5 \\
\hline Yes & & - & - & - & - \\
No & GTB & 1 & 1 & 1 & 3 \\
\hline Yes & & - & - & - & - \\
No & UBA & - & 1 & 1 & 2 \\
\hline Yes & & - & - & - & - \\
\hline No & Diamond bank & - & 1 & 1 & 2 \\
\hline Yes & & - & - & - & - \\
\hline No & & 1 & 1 & 2 & 4 \\
\hline Total & & - & - & - & - \\
\hline
\end{tabular}




\section{International Journal of Social Sciences and Management Review}

Volume: 03, Issue: 03 "May - June 2020"

ISSN 2582-0176

\section{Source: field work, 2018.}

Table 4.9 shows that all the respondents agreed that the management should be blamed for the incompetence, inefficiency, ineffectiveness and otherwise leading to bank distress.

\section{Question 20}

Do you think there are other factors that contribute to bank distress like high-unregulated interest rate, corruption indiscipline, low capital base etc.?

Table 4.10

\begin{tabular}{|l|l|c|c|c|c|}
\hline options & Bank & \multicolumn{2}{|c|}{ Department } & Total \\
\hline Yes & & Ad & A/cs & Insp. & \\
No & Polaris bank & 2 & 2 & 1 & 5 \\
\hline Yes & & - & - & - & - \\
No & GTB & 1 & 1 & 1 & 3 \\
\hline Yes & & - & - & - & - \\
\hline No & UBA & - & 1 & 1 & 2 \\
\hline Yes & & - & - & - & - \\
\hline No & Diamond bank & - & 1 & 1 & 2 \\
\hline Yes & & - & - & - & - \\
\hline No & FBN & 1 & 1 & 2 & 4 \\
\hline Total & & - & - & - & - \\
\hline
\end{tabular}

\section{Source: field work, 2018.}

From the table above 4.10, all respondents agreed that high unrequited interest rate, corruption, management indiscipline and low capital base etc. are the major cause of bank distress.

\subsection{TEST OF HYPOTHESIS}

Step 1: statement of hypothesis

Ho: The distress of banks today is due to the fact that the roles of auditors and inspectors have no effect on Banks daily operations

Hi: The distress of banks today is due to the fact that the roles auditors and inspectors have an effect on banks daily operations.

Step 2: statistical test 


\section{International Journal of Social Sciences and Management Review}

The Chi-square method is adopted to test hypothesis and the formula is $\times 2=\mathrm{k}$

$$
=\sum_{\mathrm{i}=1 \mathrm{fe}}-\mathrm{fe}^{2}
$$

Where $\mathrm{k}=$ number of cell/ categories

$$
\begin{aligned}
& \mathrm{i}=\text { the } \mathrm{i}^{\text {th }} \text { cell }(\text { where } \mathrm{I}=1,2,3 \ldots \ldots 10) \\
& \mathrm{Io}=\text { observed frequencies } \\
& \mathrm{Ie}=\text { expected frequencies }
\end{aligned}
$$

Expected frequency $=\underline{\text { Row total } \times \text { column today }}$

$$
\text { Total frequency }
$$

Step 3: specifying the significant level

The level of significance choose is 0.05 and the degree of freedom is calculated

$$
\begin{gathered}
\mathrm{Df}=(\mathrm{R}-1)(\mathrm{C}-1) \\
(5-1)(2-1) \\
4 \times 1=4
\end{gathered}
$$

Decision Rule: Reject Null hypothesis if the calculates value is greater than the critical value at 0.05 significance level and 4 degrees of freedom.

\subsection{RECOMMENDATIONS:}

The research will not be complete if it fails to address issues under the subheadings. It has been established that inspectors and external auditors are partners in the revival time banking culture in this era of bank failures. Notwithstanding their input may create the desired impact of those entrusted with the responsibility of implementing policies treat their report with relevance. This informs the researcher that for researching measures ought to be taken in order to achieve the desired result among which are:

1. Implementations of recommendation report: Management has to adjust itself to accept the efforts of auditors and inspectors as a reflection of operations in banks and at the same time implement its recommendation. It is only in a situation where the auditors/inspectors activities are recognized and their opinion suspected that blames can be apportioned to them if a failure occurs.

2. Insurance training from banking instructors: For the attainment of effective manpower training programs should be organized for staff of the inspectorate division on a regular basis. The consultancy updates their knowledge and in effect enhances efficiency.

3. Enhancement of welfare scheme: The staff of the inspectorate department of banks should be given enhanced welfare scheme in order to encourage them to perform their function with dedication and honesty. The special package of incentives is necessary to dissuade the inspectors from being bought over by perpetrators of banking fraud.

4. Commensurate remuneration for external auditors: As at now, Nigerian's underdevelopment is having its role in the lack of recognition for professional services. Professional fees paid to statutory auditors are such subjective stipends, 


\section{International Journal of Social Sciences and Management Review}

Volume: 03, Issue: 03 “May - June 2020"

ISSN 2582-0176

which cannot allow such auditors to express an independent opinion. The result is a whitewashed report which hardly highlights the actual weaknesses in the system. The research work is making a case of adequate remuneration for professional services rendered by external auditors if they must play the independent role expected of them in resuscitating availing banks.

5. Guarantee conducive environment: Management should allow both inspectors and external auditors to perform their functions without let or hindrance. Job securities should be guaranteed otherwise little or nothing can be achieved of either party under the introduction of any party.

6. Sanction of erring members of staff: sanction should be introduced in the banking sector to compel staffs of the inspectorate department to make an accurate report on fraud incidence. This will help other colleagues to learn from experience and in reducing distress in banks.

7. Use of technology: The management of banks should adopt the use of modern technology in auditing practice. The staff of the inspectorate department should be properly trained in the aspect of information technology. This will enable the staffs to carry out their duties faster, effectively and efficiently.

The above recommendations are by no means exhaustive. There are much more steps to bank management spending on the peculiar need of the banks concerned.

\section{REFERENCE}

Anyanwu, J.C. (1993), ("Monetary Economics," (P. 163-242)

Asikah, (1991), Research Methodology in Behavioral Lavice,” (Pp. 23-48)

CBN - Statistical Bulletin Financial and Economic Review. Annual report and statement of Accounts 1997-2002. (Pp6-13)

ILAN- Exam Guide, (2000), "Practical Internal audit Duties, Application and Assignment," Business Times April 13.

Ike C. N. (2000), "Direct Research for Scholars,” (Pp. 13-18)

Iyk O. Orji (2000) Qualitative Methods for Decision Making,” (Pp 10-12).

James C. Ihemeje. (2000), “Qualitative Analysis and Studies,” (Pp. 26-32)

Kontsoyiannis A., (1997), “Theories of Econometrics,” (Pp, 556-568)

Madu I. K., "Management Aided Fraud - The Auditor's Role” Business Times 1020002 (Pp. 33)

Maduasuam E., (1994), Research Principles and Methods”. Lagos (Pp 17-28).

Martins O. Onah, (1998), "Statistical Techniques for Business and Basic Science.” (Pp. 4692). 